\title{
Reggio Emilia: An Essential Tool to Develop Critical Thinking in Early Childhood
}

\author{
Mercè Fernández Santín ${ }^{1 *}$ (i), Maria Feliu Torruella² [a] \\ ${ }^{1}$ Department of Education of Social Sciences, Musical Education and Visual and Plastic Education, \\ University of Barcelona, Barcelona, Spain \{merce.fernandez.santin@gmail.com\} \\ ${ }^{2}$ Department of Education of Social Sciences, Musical Education and Visual and Plastic Education, \\ University of Barcelona, Barcelona, Spain \{mfeliu@ub.edu\}
}

Received on 5 September 2016; revised on 26 September 2016; accepted on 14 October 2016; published on 15 January 2017

DOI: 10.7821/naer.2017.1.207

(ए) WeNC-ND

\begin{abstract}
We seem to have a problem in arts education at pre-school level: the lack of specific training for teachers teaching this subject to very young children. The future preschool teachers' training seems to be focused on the teaching and learning aspects of artistic education however they receive little training on methodologies and philosophies. Therefore, when teachers have to face the classroom, the methodologies they use are usually quite traditional and do not favour the development of critical thinking skills in the students. There are different philosophies of arts education that might embed opportunities for reflection, art interpretation, experimentation, expression of emotions and feelings that if, in the case these philosophies, reach the classroom, may doubtlessly enrich the student's artistic training. Thus a conceptual framework based on one of these philosophies, named Reggio Emilia, arises. A systematic review of the literature which has been developed by categorising criteria from research papers and from examples of good practices. This categorisation might allow us to establish a framework that can be useful in the classrooms and can establish parameters of action that may have an impact on students, teachers and teachers' practice in general.
\end{abstract}

KEYWORDS: REGGIO EMILIA, ART EDUCATION, CRITICAL THINKING

\section{INTRODUCTION}

Training for teachers teaching arts at preschool level seems to be missing from academic programmes as the training received by future preschool teachers is far from what would be ideal. Therefore, we find arts teachers who have not studied fine arts and arts history or that have only studied a couple of subjects throughout their teaching training programmes.

Although there seems to be an education renewal in regards to training teachers, it is not yet visible in the classrooms. Besides, there is very little research in preschool arts education that

\footnotetext{
*To whom correspondence should be addressed:

University of Barcelona, Factultad de Educación - Campus Mundet, Sección Departamental de Didáctica de las Ciencias Sociales, Edificio de Llevant, Despacho 125, Pg. Vall d’Hebron 171, 08035 Barcelona, Spain
}

allows us to draw conclusions. On the other hand authors like Eisner (2002), Sans and Balada (2004; 2008), Acaso (2009) mention the importance of changing attitudes and practices in relation to arts education at preschool level.

Teachers undergoing training should consider two different strands: lack of training in arts and lack of training in pedagogy, depending on the levels in which they are teaching. A good example is described by Acaso (2009) who points out that in Spain secondary education teachers have arts training but they do not possess education and pedagogic related training, while primary school teachers have strong pedagogic training but they lack training and education in relation to arts. Therefore, we consider that teacher training in artistic education must point in two directions: a deep pedagogical improvement on teaching skills and knowledge including new theories, paradigms, methodologies and innovative means for teaching, and to develop strong knowledge in the arts, its movements and its history, therefore, this study aims to provide a conceptual framework that can help to fill the existing gaps in teachers education. The core issue with the lack of knowledge in arts education is that it can strain the innovation in the classroom because teachers are missing key theoretical and philosophical elements to teach arts. In recent years, there has been some debate in schools to redesign arts teaching in preschool and primary school. However, there is a scarcity of consistent strategies to allow teachers, who are not being trained in arts teaching, to develop the full potential of arts education in the children's critical thinking.

To understand how art is taught at preschool level is key to studying which are the most commonly used methods to teach arts to young children in order to determine whether the use of methods such as the Reggio Emilia approach are effective to develop creativity in young children.

Our research is based on the concept of the arts atelier, which is at the heart of the educational model developed by Loris Malaguzzi at Reggio Emilia. It can be understood as a philosophical approach which is focused on listening and respecting children and their potential by witnessing their actions towards reformulating everyday practices, ideas and projects. The approach proposes a participatory and democratic educational system, that emphasises research and experimentation and which is one of the many educational approaches to arts education in childhood. 
We understand arts education as the one of the types of educational models that allows the awakening of critical thinking from artistic works as critical thinking is achieved when attitudes, emotion and expression of feelings are developed and when reflection and interpretation are stimulated. Thus, arts education contributes to the children's critical thinking.

The Reggio Emilia approach promotes art education, which is seen as a way to develop critical and scientific thinking through artistic work, stimulating values and encouraging children to express their feelings, promoting the development of communication and social skills and motivating cooperative work and discussion as key elements in a free and democratic society. (Ciari, 1961; New, 2007; González, 2011). According to New (2007), “Reggio Emilia's municipal early childhood program (...) is committed not to the development of more and better child artists, but to the development of creative, critically thinking and collaboratively engaged citizens”.

Artistic training in early childhood education it is based on plastic experimentation (colours, textures, materials) and on creating standardised projects in which freedom of expression and individual creativity is not yet present. Usually, critical thinking strategies are not embedded in arts education, which do not seem to go beyond the strictly manual and plastic abilities. When we limit our practices to this sort of methodology only we do not develop all the possibilities that arts teaching philosophies can offer us.

The most known or common methods of arts education can be understood as follows: Discipline-Based Art Education (DBAE); Bauhaus and Visual Thinking. The authors behind arts related educational theories are Eisner, Gardner, Read, Lowenfeld, Montessori and Waldorf.

Our main objective is to present a framework that can support the adoption of the atelier of Reggio Emilia as a key element to develop critical thinking since early childhood from pre-school, by supporting teachers to develop strategies that can lead to establish an arts related pedagogical model.

Also, is important to highlight that teachers' education in arts education is key in supporting them to choose to adopt different approaches to develop critical thinking skills in young children, therefore, if innovative or non-traditional models are not been taught at the schools of pedagogy or education, arts teachers might tend to adopt very traditional approaches, related to their own experiences in learning how to teach arts, consequently they might tend to choose a rather orthodox model in the classroom, instead of experimenting with new possibilities. Ergo, for us is key -via this research- to be able to present a model that can be used at schools and also for teacher training.

Our research is focused on understanding if by adopting the Reggio Emilia approaches and model it is possible to support an effective method to develop creative thinking skills for the early childhood, to achieve this, we aim to conceptualise the benefits and challenges of using the aforementioned pedagogical approach in the curricular development of arts teaching

This paper conceptualises and defines the key approaches and methods for arts education, presenting a scope to understand different methodologies towards developing creative thinking through arts. Through rigorously analysing the literature we aim to systematise a pedagogical approach towards developing a conceptual framework to support the implementation of Reggio Emilia methodologies at pre-school and primary school levels, leading towards good practices in arts teaching and learning.
To support the implementation of the Reggio Emilia's atelier in schools, in this paper a conceptual framework is presented towards facilitating the adoption of a model able to help teachers in training. This conceptual framework can be useful in the arts education classrooms, as it establishes parameters that can have an impact on students, teachers and in the methodology in general.

\section{CONCEPTUAL BACKGROUND}

With regards to the concept of arts education, this has changed its focus and trends over the time and is constantly evolving. The trends relating to arts education in schools, have been modified, extended, corrected and reinvented. Throughout the literature review, several trends in art education can be identified; such as the Discipline-Based Art Education (DBAE) and the Bauhaus.

The DBAE as model focuses on arts teaching through the visual art and aims at four objectives: to create; to appreciate the qualities; to relate art to its socio-cultural context, and to explain and justify their own judgments. The concept of Bauhaus, which is related to the field of design and, at the school framework, seeks to help students to become aware of a variety of considerations of the economic, structural and aesthetic aspects in the design process, which has to be the result of a personal creative expression.

One of the pioneers in analysing visual thinking is Rudolph Arnheim, who was influenced by the Gestalt and Hermeneutics movements, in his book Visual Thinking (1969) he suggests that there are other ways of learning based on the senses, such as through vision. Therefore, following this line of thought we can find Elliot W. Eisner and Howard Gardner amongst other theorists, both of whom developed their own approaches with regards to arts and creativity.

Eisner (2002) considers artistic thinking as a dynamic, relational, constructive and poetic construct that provides a particular way of conceiving reality. He describes an active subject that participates in symbolic interpretations. Gardner (1993), suggests that the artistic abilities are mind activities that involve the use and transformation of symbols and, due to its complexity, it is necessary to train teachers because they have to design and evaluate the experiences of their students.

Another theorist, Read (1943) understands arts as a process that frees the mind and provides a "constructive exit" for the expression of ideas and feelings. He argues that art is the product of spontaneity, creativity and individual talent, which have as a starting point aesthetical sensibility. On the same path, Lowenfeld publishes the book Creative and Mental Growth (1947) where he describes the characteristics of the artistic productions of children at each stage as: scrawl, pre-schematic, schematic, early realism, pseudo-naturalism and decision.

\section{RESEARCH METHODOLOGY}

For this study, and with the aim of developing a conceptual and theoretical framework, consistent and systematic literature has been developed following the guidelines of Grant \& Booth, (2009) and the EPPI Centre (2007) Jesson, Matheson \& Lacey (2011), and Booth, Papaioannou \& Sutton, to allow us to describe and understand a vision of artistic training in early childhood education and also allow us to understand how the pedagogical model of Reggio Emilia can be applied in the art classroom. 
To ensure that the review was systematic, we followed the following EPPI-Centre (2007) recommendations:

(1) Searching for studies: an electronic database searching for papers, books, conferences was done using specific keywords, Reggio Emilia, Art Education, Critical Thinking. We also carried out handsearching on key paper references and asked experts in the field.

(2) Scoop the review: from a database review, 58 papers were obtained however 27 of them did not contain enough information about Reggio Emilia or were not focused on the field. We categorised the remaining 24 into study cases and theoretical papers. From the case studies we obtained examples of good practices and from the theoretical papers we obtained philosophical and theoretical analysis, which allowed us to structure the conceptual framework of this study.

(3) Describing and mapping: we synthesized the details from each group of studies gathering information about descriptive information and results. Also, we outlined the methodology and results from each included study. We were able to make a systematic description according to the criteria.

(4) Quality and relevance appraisal: Using a technique based on the principles of peer review, papers were assessed and scored in regards to their quality and relevance for this study, ensuring that the methods, concepts and definitions were evidenced in an appropriate manner to ensure that the sources used in this research were academically relevant.

(5) Synthesising study findings: we established relations between Reggio Emilia's main connection with the literature in order to establish links. Once these connections were established, a set of relevant concepts were drawn and structured towards designing a consistent approach to the core elements of the philosophy of Reggio Emilia.

(6) Conclusions: we designed a set of recommendations linked to the findings of the study.

\section{DELIMITATION OF THE STUDY}

We believe that, if during pre-school, teacher and schools adopt into their curricular development approaches and methods such as Reggio Emilia to enhance arts education with their students, it can potentially allow the development of creative thinking by facilitating spaces to develop creativity.

The main objective of this study is to develop, through the literature review, a conceptual framework that can enable the implementation and embedding of the Reggio Emilia conceptualisation model and philosophy at schools to become a guide for educators and schools than can effectively be established.

The literature reviewed relates to the philosophy of Reggio Emilia and adjacent theories. During the research, the articles have been classified according to key three areas:

Philosophy: The philosophy of Reggio Emilia schools.

Lessons: What can educators and researchers learn from the Reggio Emilia approach.

Applications: How can we apply the Reggio philosophy within the classroom.

\section{LITERATURE REVIEW. RESULTS}

In this literature review we have found that, at pre-school level, during the students' artistic process, the teachers may limit the children's creativity as by often requesting activities aimed at copying, reproducing or reinterpreting a specific work of art or artist (Trowbridge, 2010; Capace, 2012; O'Hanley, 2013; Aguilar, 2013; Martinez, 2015). Therefore, it is possible to assume that the model used to teach art in schools may inhibit the full potential of the creative process of children by restricting them (Gonzalez, 2011; Bartel, 2014).

According with Gonzalez (2011) very often we can find cases where the teacher predicts the answer he/she wants to receive from the students and leads them to it, therefore, not allowing different contributions. We can infer that this model may limit the children's creativity when they are working as often their work looks for a final result aimed to reproduce or copy.

On the other hand and in relation to the previously mentioned models, Reggio Emilia can help the children to represent and to communicate their thinking throughout different means and symbolic systems. The language used by the children are the sources that generate knowledge, amongst these, art plays an important role. Several authors like Gardner (1993), Malaguzzi (1998) and Eisner (2002), who study the child as an artist, refer to creativity without limits or restrictions, which children have during the pre-school. Therefore, everything children cannot experience or create freely during this period, ,will not be recoverable.

\subsection{Children's art understood by the Reggio Emilia approach}

Reggio Emilia, as philosophical approach, is focused on listening and respecting the children for the potential of witnessing their actions, towards reformulating everyday practices, ideas and projects. The schools associated with the Reggio Emilia philosophy, propose a participatory and democratic educational system, that emphasises research and experimentation.

The cultural project of its founder, the pedagogue Loris Malaguzzi, has the child as the main priority and not the subject to teach therefore, the learning process is key, and not just the final product. For this reason it is necessary for both teachers and learners to observe, document and discuss.

Malaguzzi (1993) proposed that art teaching needs to become an identity trademark for two fundamental reasons towards developing learning during early childhood.

- The creation of the atelier where the central figure is the person called an atelierista, who is in charge of the atelier. The role of the atelierista is to generate situations that promote experimentation and research so they can be conducted. And also, to accompany the children on finding their discoveries. Giving them also opportunities to experience and to be experienced.

- In Reggio Emilia, the key interests are framed towards stress on the importance of the creativity at metaphorical, symbolical level, aiming at developing research projects amongst the students. Also, at Reggio Emilia schools, they work around the way we see and how we think about the world and about ourselves in the world. As creativity can have an effect on the different ways of expressing language among the children. 
The research projects start from the interest of children and might be based on their experiences, exploration, or from the questions they may have about the world that surrounds them. Throughout the projects, children develop cognitive, social and language skills.

\subsection{Conceptual development of the Reggio Emilia theory}

After World War II, Malaguzzi founded a network of municipal schools in the Reggio Emilia region of Italy. The people of a village in Reggio Emilia decided to build and manage a school for the children of the village, which was funded from military equipment abandoned by the Germans (a tank, a truck and several horses). A school was born from the desire and enthusiasm of the residents to make changes. Other schools on the periphery followed the project later. All were created and self-managed by the villagers. Loris Malaguzzi finally joined the project in 1963 and created the first municipal school.

The school is considered a unitary living organism, a place of coexistence to exchange relationships between adults and children. A place where students can think, discuss and learn how to work by trying to reconcile what they know and what they do not know, their difficulties, failures, expectations, success, the questions and problems that are always present when they have to choose (Malaguzzi, 1993).

The Reggio Emilia approach, can be understood from the conceptualisation in which several authors define Reggio Emilia by analysing its origins, main features, characteristics and philosophy, and its practical application in schools (Fiore \& Scuola, 1991; Firlik, 1994; Isbell 1999; Sassalos, 1999; Bennett, 2001; Edwards, Gandini, \& Foreman, 2001; Hertzog, 2001; Edwards, 2002; Loh, 2006; Vecchi, 2013; Cutcher, 2013).

Sassalos (1999) and Bennett (2001) have self-reflected about their own methodologies in the classroom. Other authors like Kim and Darling (2009) define Reggio Emilia by describing a project about Monet that showcases how children develop their understanding throughout conversations and discussions between them and the teachers, co-constructing their knowledge. Meanwhile, Herzog (2001) and New (2007) analyse why this approach has raised interest and, indeed has succeed in countries like the United States.

According to Loe (2006), the Reggio Emilia approach is characterised by six key aspects that define and differentiate it: 1. documentation; 2 . The environment as third teacher; 3 . The multiple languages of the children; 4 . Long-term projects; 5 . The teacher as researcher and 6. The home-school relationships (Loh, 2006).

In turn, Kim and Darling (2009) think that these six aspects should be complemented with another three main themes which are: 1 . The image of the child; 2 . The negotiated learning; and 3. social relationships which define the meaning of the pedagogy of the kindergarten schools associated to the model developed by Malaguzzi.

\subsection{Core areas of the Reggio Emilia theory}

Therefore, the main focuses (RE1-RE8) of the Reggio Emilia approach drawn from the literature review can be defined as:

- The environment as third teacher. (RE1) Reggio Emilia schools pay special attention to the environment, therefore, are designed to inform and include students and school visitors (Schroeder-Yu, 2008). The approach describes three educators at the same time: the teacher, the student and the environment (Strong-Wilson \& Ellis, 2009). The aesthetic, the beauty of the schools and the classroom atmosphere are pampered and cared for in detail. The teachers organise the space in a way that is inviting for students to explore, experiment and investigate.

- The multiple languages of the children. (RE2) In the Reggio Emilia schools, the arts are integrated as tools for cognitive, linguistic and social development. The teachers use arts as a vehicle to understand the thinking process of the students (Bennett, 2001). As Vecchi (2013) mentions, in the Reggio approach, it is decided to extend the term "language" beyond verbal languages and is considered as the different ways in which language is used by human beings to express themselves: visual language, mathematical language, scientific language, etc.

- Long-term projects. (RE3) The projects, which can be short (one week) or long term (one academic year), are focused on the interests of the students, therefore, the teachers help the students to make decisions regarding the directions in which to take over the research (Loh, 2006).

- The teacher-researcher. (RE4) In the Reggio Emilia approach, the teachers' role is not reduced only to provide information to students, but to listen, observe and to document the work of children.

- The image of the child (RE5) is considered a powerful, competent, creative, curious, full of potential and ambitious entity (Malaguzzi, 1993). Hence, the child is considered a researcher with the ability to question and experiment. Thanks to the projects, the students are able to co-construct knowledge through discussions with their teachers and classmates. The projects, used as research strategies are born from the children's interests that come from their experiences, their exploration and the questions they might have about the world that surrounds them. Through the projects, children can acquire cognitive, physical, social and language skills. Also, as they apply these skills into different contexts and situations, they may gain independence and confidence, taking their own decisions and responding to their own problems.

- Negotiated Learning (RE6) in this context, students coconstruct their learning through working in social groups. Reggio Emilia educators, give much importance to the debates, the negotiations and to students solving problems cooperatively. Teachers, therefore, must generate strategies to support students interacting amongst themselves, as throughout the negotiation, the students are able to generate knowledge.

- Documentation (RE7) through photographs, films, sound and voice recordings and, notes, etc., it's possible to present and represent the experiences, thoughts and ideas of the students and to showcase their learning processes. Through the documentation, it is possible to assess the importance and relevance to the work of the students and to make it visible. Moreover, the documentation promotes communication and collaboration between students, teachers and families by creating a meaningful dialogue (Rinaldi, 2001). In the day-to-day activities, Reggio Emilia, schools use of documentation as a tool for sharing and to construct basic knowledge because according with Schroeder-Yu (2008) "Dialogue and recorded 
conversations offer opportunities to reveal how individuals and groups of learners create meaning of subjects” (p. 131), for Moran, Deschrochers and Cavicchi (2007), the use of documentation in schools changes, progressively, educational practices. For Filippini, being interviewed by Turner and Wilson (2009) "Documentation seeks to develop new relationships on how we know children and how they know themselves" (p. 7)

- Social relations. (RE8) Reggio Emilia's philosophy is based on social constructivist theories, which define children as social active actors in the construction and determination of their social lives. According to Malaguzzi (1993), children are far from being passive students without structures and social processes. The relationship between students and teachers, help to make co-constructive learning as they create opportunities to generate ideas emerging from the cognitive conflict.

\section{DISCUSSION}

Regarding the lessons, after a comprehensive analysis of the Reggio Emilia approach, its work, its architecture, the environment, and other core elements, a number of implications are generated, which can be useful for other teachers and researchers interested in Reggio Emilia. Therefore, it can be a starting point for the implementation of this educational philosophy in other schools. However, the result of these investigations arise in relation to understanding if it is possible for the Reggio Emilia approach to be applied and implemented in schools located outside this Italian region (Katz, 1994; Bennett, 2001; Tarr, 2001).

In regards to the applications, from the study of the Reggio Emilia approach, practices are generated within the classroom and projects are impregnated with this philosophy (RE1) (Sassalos, 1999; Kim \& Darling, 2009), and as for Sassalos (1999) "there are many ideas that may be taken from the schools of Reggio Emilia" (p. 20). As a start point one of the characteristic features of Reggio Emilia, the use of the documentation: how can we make students feel they are part of a school community through an exhaustive process of documentation (RE7) (Schroeder-Yu, 2008)?

Following the same research line, and according to Moran Desrochers and Cavicchi (2007) “documentation was used by children to invite others into their learning and it inspired many similar displays throughout the school (...) it conveyed children's belief that because others valued their work, they must want to be part of it (...) enabling teachers to share ideas and inspire others to try out new ways for using documentation to plan relevant curricula for children” (p. 86). (RE7 \& RE5) It is showcased how, with the proper use of documentation and projects, the learning community can be changed (Moran, Desrochers, \& Cavicchi, 2007; Schroeder-Yu, 2008). (RE3)

In Reggio Emilia, there is an exceptional care towards inclusion, particularly for students with special educational needs. As Gilman (2007) explains "Inclusion is embraced in the Reggio Emilia approach. Children with special needs are regarded as worthy” (p. 26). Also, the games are considered one of the 100 languages of the child, as for Fraser (2007) "in Reggio Emilia, therefore, play is considered an essential childhood activity and one of the hundred languages, but it seems that it is the relationships that occur within the play that are given the greater focus” (p. 15). (RE2 \& RE8)
So, based on this premise, where in class groups in which cultural diversity (and language) is considerable, it is possible to start observation of the games amongst students, to identify issues of interest in the children and thus, to develop projects which can be meaningful for the children, Fraser (2007). (RE3 \& RE4) Finally, Mitchell (2009) considers how they can integrate technology programs inspired by the Reggio Emilia Approach, as for him "Reggio Emilia, Italy, and other centres around the globe inspired by the Reggio Emilia approach, offer many ideas for how to incorporate the use of technology.” (p. 38)

Regarding the role of the environment as the third teacher, it is important to take care of the aesthetic environment, the space flexibility, the transparency of objects, the materials used in the classroom are aspects that favour this third role of the environment as a teacher, as used so often in Reggio Emilia (Tarr, 2001; Strong-Wilson \& Ellis, 2007) (RE1). Moreover, Reggio Emilia promotes the capability to generate knowledge of students through flexible long-term projects that includes educational strategies as games and discussions between themselves or between the student and teachers, as these can be helpful to refute or to validate ideas (Fraser, 2007; Kim \& Darling, 2009). (RE3 \& RE6)

\section{CONCLUSIONS}

From the literature review, we have identified the following concepts:

\section{- Reggio Emilia approach \\ - Lessons \\ - Applications}

These concepts (the environment as a third teacher, documentation or the image of the child) are useful to understand the schools of Reggio Emilia, which are the source of inspiration for its methodology, how schools are structured, how they work, how students learn, how they relate to each other, with the teachers and with other educational communities, what role the teacher plays, how the relationship between schools and families is, which aspects can be applied to schools in the rest of the world, and what we can learn as teachers and researchers.

As Vecchi explains (2013) the atelier should be a big space visually connected with the rest of the school and it must be properly equipped, according to her "Along with digital material, they must have lots of traditional material such as: crayons, clay, paint, wire, scissors, recycled materials, etc. Tools and materials that enable students to have experiences in which their thoughts take different forms (visual, musical, dance, verbal)." (p. 56).

Based on this concept, a model of working parameters can be established (Table 1).

It is interesting to keep in mind these ideas about Reggio Emilia in order to establish a framework of action for the implementation of the Reggio Emilia model in schools, in order to develop guidelines for teachers and schools through a work where students are invited to experience art through playing and imagination, using different languages as the creative response of children has no limits and must not be guided through playback or copy. We believe that this framework can be used as a good practice guide to present a new perspective to encourage innovation in the professional development of teachers and also 
Table 1. Conceptual framework

\begin{tabular}{|c|c|c|}
\hline $\begin{array}{l}\text { CONCEPT applied } \\
\text { to the ATELIER }\end{array}$ & $\begin{array}{c}\text { IMPACT ON } \\
\text { STUDENTS } \\
\end{array}$ & $\begin{array}{l}\text { IMPACT ON } \\
\text { TEACHERS }\end{array}$ \\
\hline \multirow{2}{*}{$\begin{array}{l}\text { Environment as the } \\
\text { 3rd Teacher }\end{array}$} & $\begin{array}{l}\text { They invite students } \\
\text { to explore, investi- } \\
\text { gate, experiment and } \\
\text { ask questions about } \\
\text { the world around } \\
\text { them. }\end{array}$ & $\begin{array}{l}\text { Sensitivity to the } \\
\text { appearance of the } \\
\text { school and its sur- } \\
\text { roundings. }\end{array}$ \\
\hline & $\begin{array}{l}\text { Common areas that } \\
\text { allow students from } \\
\text { other classes to meet. }\end{array}$ & $\begin{array}{l}\text { Create an environ- } \\
\text { ment rich in possibil- } \\
\text { ities and challenges } \\
\text { that invites to team- } \\
\text { work, to explore and } \\
\text { to solve problems. }\end{array}$ \\
\hline \multirow[b]{2}{*}{$\begin{array}{l}\text { Hundred Languages } \\
\text { of the children }\end{array}$} & \multirow{2}{*}{$\begin{array}{l}\text { Use of the arts as a } \\
\text { symbolic language to } \\
\text { express their } \\
\text { knowledge in pro- } \\
\text { jects. }\end{array}$} & $\begin{array}{l}\text { Integration of graphic } \\
\text { arts as a cognitive } \\
\text { tool, linguistic and } \\
\text { social. }\end{array}$ \\
\hline & & $\begin{array}{l}\text { Presentation of } \\
\text { concepts and hypoth- } \\
\text { eses in different } \\
\text { ways: painting, } \\
\text { theatre, writing, } \\
\text { shadow theatre, etc. }\end{array}$ \\
\hline Projects & $\begin{array}{l}\text { Based on the interest } \\
\text { of students. }\end{array}$ & $\begin{array}{l}\text { To help students to } \\
\text { make decisions about } \\
\text { which direction to } \\
\text { take in their studies. }\end{array}$ \\
\hline \multirow{3}{*}{ Teacher-Researcher } & \multirow{3}{*}{$\begin{array}{l}\text { Provoke and stimu- } \\
\text { late their students } \\
\text { thoughts }\end{array}$} & $\begin{array}{l}\text { Role of the teacher- } \\
\text { researcher: to listen, } \\
\text { to observe and to } \\
\text { document their } \\
\text { students' work. }\end{array}$ \\
\hline & & $\begin{array}{l}\text { Commitment towards } \\
\text { educational practice } \\
\text { and learning. }\end{array}$ \\
\hline & & $\begin{array}{l}\text { Cooperative work } \\
\text { with other teachers to } \\
\text { share information. }\end{array}$ \\
\hline \multirow{3}{*}{ Image of the child } & $\begin{array}{l}\text { Little researcher: } \\
\text { ability to question } \\
\text { and investigate. }\end{array}$ & \multirow{3}{*}{$\begin{array}{l}\text { Propose projects } \\
\text { focused on the } \\
\text { interests of children. }\end{array}$} \\
\hline & $\begin{array}{l}\text { Acquisition of au- } \\
\text { tonomy, independ- } \\
\text { ence and confidence. }\end{array}$ & \\
\hline & $\begin{array}{l}\text { Making decisions } \\
\text { and solving difficul- } \\
\text { ties. }\end{array}$ & \\
\hline Negotiated Learning & $\begin{array}{l}\text { Co-construction of } \\
\text { learning through } \\
\text { social relationships. }\end{array}$ & $\begin{array}{l}\text { Generate strategies } \\
\text { that help students to } \\
\text { interact with each } \\
\text { other (debates, } \\
\text { problem resolution, } \\
\text { teamwork, etc.). }\end{array}$ \\
\hline \multirow[b]{2}{*}{ Documentation } & $\begin{array}{l}\text { The opportunity to } \\
\text { express, build and } \\
\text { validate their ideas, } \\
\text { knowledge and } \\
\text { emotions. }\end{array}$ & $\begin{array}{l}\text { Opportunities to } \\
\text { share with the educa- } \\
\text { tional community } \\
\text { (teachers, families, } \\
\text { researchers) working } \\
\text { class. }\end{array}$ \\
\hline & $\begin{array}{l}\text { Help students to keep } \\
\text { track of their learning } \\
\text { and make it visible. }\end{array}$ & $\begin{array}{l}\text { The teacher collects } \\
\text { information on the } \\
\text { students work (with } \\
\text { photos, videos, } \\
\text { audio, collection of } \\
\text { written notes taken } \\
\text { from observations). }\end{array}$ \\
\hline \multirow{2}{*}{$\begin{array}{l}\text { Family-school Rela- } \\
\text { tionships }\end{array}$} & $\begin{array}{l}\text { Facilitate learning } \\
\text { about the world } \\
\text { around us. }\end{array}$ & \multirow{2}{*}{$\begin{array}{l}\text { Teamwork between } \\
\text { students, teachers } \\
\text { and families. }\end{array}$} \\
\hline & $\begin{array}{l}\text { Education based on } \\
\text { social relationships. }\end{array}$ & \\
\hline
\end{tabular}

to provide a set of useful guidelines to enhance the curricula for arts teacher training in university programmes, because it allows us to rethink, from an innovative, simple and effective pedagogical model about the role of art in the education of infants; in order to stimulate and develop critical thinking from arts education.

It can be also helpful for arts students interested in education by offering them interesting and novel methodologies, such as the Reggio Emilia approach, which differ from the traditional techniques of reproduction or artistic works to teach arts, offering alternatives to develop, through arts education, critical thinking and creativity, relating both with the world and with others.

\section{ACKNOWLEDGEMENTS}

Funded by: Government of Catalonia, Spain.

Funder Identifier: http://dx.doi.org/10.13039/501100002809 Award: 2014SGR000945

\section{REFERENCES}

Acaso, M. (2009). El lenguaje visual. Barcelona: Paidós.

Aguilar, B. (2013, November 22). Pintamos como Van Gogh, La noche estrellada [Blog post]. Retrieved from

http://blogdelamaestraberta.blogspot.com.es/2013/11/pintamos-como-vangogh-la-noche.html

Bartel, M. (2014, January 2) Teaching Creativity. Retrieved from https://people.goshen.edu/ marvinpb/arted/tc.html

Bennet, T. (2001). Reactions to Visiting the Infant-Toddler and Preschool Centers in Reggio Emilia, Italy. Early Research and Practice, 3(1)

Capace, B. (2012, April). Pintamos como Joan Miró [Blog post].

Cheryl, T. (2010, January 13). Picasso Portraits-Kindergarten Style! Retrieved from http://www.teachkidsart.net/picasso-portraits-kindergarten-style/

Cutcher, A. (2013). Art Spoken Here: Reggio Emilia for the big kids. International Journal of Art \& Design Education, 32, 318-330. doi:10.1111/j.14768070.2013.12028.x

Eisner, E . (2002) El arte y la creación de la mente. Yale University Press.

Edwards, C., Gandini, L., \& Forman, G. (1998). Hundred Languages of Children: The Reggio Emilia Approach -Advanced Reflections. Greenwich: Ablex Publishing Corporation.

Fiore, A., \& Scuola, L. (1991). The Reggio Emilia Approach to Early Childhood. Retrieved from

http://tykesntotsdaycare.weebly.com/uploads/5/3/9/7/53974635/the_reggio_ emilia_approach_to_early_childhood.pdf

Firlik, R. (1996). Early childhood education and beyond: Can we adapt the practices and philosophies from the preschools of Reggio Emilia, Italy into our elementary schools in America? Early Childhood Education Journal, 23(4), 217220.

Fraser, S. (2007). Play in Other Languages. Theory into Practice, 46(1), 14-22. doi:10.1080/00405840709336544

Gardner, H. (1993). Inteligencias multiples: La Teoría en la práctica. Espasa Libros.

Gilman, S. (2007). Including the Child with Special Needs: Learning from Reggio Emilia. Theory into Practice, 46(1), 23-31. doi:10.1080/00405840709336545

González, M. (2011). El arte en las escuelas no es un juego de niños. Errata, 4, 2140.

Hertzog, N. B. (2001). Reflections and Impressions from Reggio Emilia: "It’s Not about Art!”. Early Childhood Research \& Practice, 3(1).

Jesson, J., Matheson, L., \& Lacey, F. M. (2011). Doing your literature review: Traditional and systematic techniques. London: Sage.

Katz, L. G. (1994). Images from the world: Study seminar on the experience of the municipal infant-toddler centers and preprimary schools of Reggio Emilia, Italy. Reflections on the Reggio Emilia Approach, (3), 7-19.

Kim, B. S., \& Darling, L. F. (2009). Monet, Malaguzzi, and the Constructive conversations of Preschoolers in a Reggio-inspired classroom. Early Childhood Education Journal, 37(2), 137-145. doi:10.1007/s10643-009-0323-2

Loh, A. (2006). Reggio Emilia Approach. Retrieved from http://www.brainychild.com/article/reggioemilia.shtml

Malaguzzi, L. (1993) La educación infantil en Reggio Emilia. Madrid: Ediciones Octaedro.

Martínez, E. (2015, July 28). Pintamos como Van Gogh A grandes pinceladas [Blog post]. Retrieved from 
http://elrincondeinfantiljuancarlos1.blogspot.com.es/2015/07/pintamos-comovan-gogha-grandes.html

Mitchell, L. (2009). Using Technology in Reggio Emilia-Inspired Programs. Theory into Practice, 46, 32-39. doi:10.1080/00405840709336546

Moran, M. J., Desrochers, L., \& Cavicchi, N. M. (2007). Progettazione and Documentation As Sociocultural Activities: Changing Communities of Practice. Theory Into Practice, 46(1), 81-90. doi:10.1080/00405840709336552

New, R. S. (2007). Reggio Emilia As Cultural Activity Theory in Practice. Theory Into Practice, 46(1), 5-13. doi:10.1080/00405840709336543

O’Hanley, H. (2013, April 17). Kindergarten Pop Art with Andy Warhol [Blog post]. $\quad$ Retrieved from http://talesfromthetravellingartteacher.blogspot.com.es/2013/04/kindergarten-popart-with-andy-warhol.html

Pope Edwards, C. (2003). "Fine Designs” from Italy: Montessori Education and the Reggio Emilia Approach. Montessori Life, 15(1), 34-39. Retrieved from http://digitalcommons.unl.edu/famconfacpub/20/

Sans, S., \& Balada, M. (2004-2008). Col-lecció Fragments. Taller de plàstica Carrau Blau. Referents per a la didàctica a l'escola. Barcelona: Rosa Sensat.

Sassalos, M. (1999). Discovering Reggio Emilia, Building Connections between Learning and Art. 35(23). Retrieved from http://eric.ed.gov/?id=ED456890

Schroeder-Yu, G. (2008). Documentation: Ideas and Applications from the Reggio Emilia Approach. Teaching Artist Journal, 6(2), 126-134. https://doi.org/10.1080/15411790801910735

Strong-Wilson, T., \& Ellis, J. (2007). Children and Place: Reggio Emilia’s Environment As Third Teacher. Theory Into Practice, 46(1), 40-47. doi:10.1080/00405840709336547

Tarr, Patricia. (2001). Aesthetic Codes in Early Childhood Classroom: What art educators can learn from Reggio Emilia. Art Education, 54(3), 33-39. doi: $10.2307 / 3193922$

Turner, T., \& Wilson, D. G. (2009). Reflections on Documentation: A Discussion With Thought Leaders From Reggio Emilia. Theory Into Practice, 49(1), 5-13. doi:10.1080/00405840903435493

Vecchi, V. (2013) Arte y creatividad en Reggio Emilia. El papel de los talleres y sus posibilidades en educación Infantil. Abingdon: Ediciones Morata.

How to cite this article:

Fernández, M. \& Feliu Torruella, M. (2017). Reggio Emilia: An

Essential Tool to Develop Critical Thinking in Early Childhood.

Journal of New Approaches in Educational Research, 6(1), 50-56.

doi: 10.7821/naer.2017.1.207 